\title{
8
}

\section{Youth's Displaced Aggression in Rural Papua New Guinea}

\author{
Imelda Ambelye
}

\section{Introduction}

Papua New Guinea (PNG) has significant land resources and close to 80 per cent of all land in the country is customary owned, either by individuals or by some form of clan ownership; it is thus governed by traditional land tenure systems. Most people meet their basic needs through subsistence agriculture and a large part of the rural population and, to a lesser extent, the urban population relies on forest products, fishing, hunting and subsistence agriculture for their livelihoods (UNESCO 2007a). About 87 per cent of the population in PNG lives in rural areas, most of which are not accessible by road. The country is culturally and ethnically highly diverse, as well as deeply politically fragmented. Dealing with this fragmentation within the postcolonial nation state entails numerous economic and social challenges.

PNG's extractive industry is booming and attracting economic benefits in the form of revenue for the government, royalties for landowners and jobs for many communities and villages living around the mining, gas and oil sites. The extractive industries in PNG are a major economic driver, creating jobs, revenue and opportunities for growth and development. Theoretically, material resources are thus available to provide an enabling environment for women and youths to identify their own goals and to reconstruct their reality (Kabeer 1999). Logically, it should follow that 
men, women and young people in the villages who are affected by the extractive industries would be more empowered and thus better able to participate and contribute to community development, but this often does not happen (Cornwall 2016; Sholkamy 2010). Most women and youths in the villages and communities of PNG are not empowered, including those affected by the resources boom.

This chapter shows the problems and challenges that youths face in the rural villages of PNG. Youths here are those aged between 15 and 33 years. Most of these youths have been educated to secondary and post-secondary education and return to the villages because they cannot continue to live elsewhere due to limited opportunities and resources. The antisocial behaviour demonstrated by some reflects their frustration and displaced aggression. This chapter begins by examining youth in two villages and their livelihoods. Then, a case study is presented to use the theme that emerges for discussion. The main theme on antisocial behaviour and its implications is followed by a discussion of how such behaviour is a reflection of the broader social, economic and political climate of PNG.

\section{Background and Setting}

In this section, I will outline the general socioeconomic and infrastructural setting in the two villages of Lealea and Kugmumb. These two villages are where I lived and conducted my doctoral fieldwork for six months in 2015 and a month in 2017, focusing on youths, especially educated young women and empowerment. Lealea is a coastal village in the Central Province and Kugmumb is a village in the Western Highlands.

\section{Lealea}

The village of Lealea (Rearea) is a coastal village with a population of about 2,936 people (NSO 2011). It is in the Central Province of PNG, in the Kairuku-Hiri district and in the Hiri Rural Local Level Government. Kairuku-Hiri district surrounds Port Moresby and stretches from the Gulf Province to Gaire Village, southeast of Port Moresby (NRI 2010). Hiri covers four coastal villages in Hiri West, and Kairuku-Hiri District in Central Province in PNG covers approximately $30 \mathrm{~km}$ west of Port Moresby. Three villages (Lealea, Boera and Porebada) are Motuan and one (Papa) is Koita (the Koita are referred to as Koitabu by the Motuan 
people). The Motu are an essentially maritime people; villagers engage in fishing, hunting and gardening activities to sustain their daily livelihoods. Other income includes small-scale commerce (e.g. trade stores and street markets) and working for the PNG Liquefied Natural Gas (LNG) project. All villages lie within a $5 \mathrm{~km}$ radius of the PNG LNG facility and are classified as resource development impact areas or as communities.

\section{Kugmumb}

With a population of 702, Kugmumb is located in the Mt Hagen Rural Local Level Government, Hagen District, Western Highlands Province. It is less than $15 \mathrm{~km}$ from Mt Hagen (NRI 2010) and is in a province that does not have any extractive industry. Subsistence agriculture and cash cropping are common. Coffee plantations have created higher incomes for people in the Wahgi, Kuna and Komun Valleys. The land is fertile and it produces good food yields for subsistence livelihoods. Within this region, agricultural potential is relatively high, as are incomes, and access to services is reasonably good, with the exception of the steep slopes of the Hagen and Kubor Ranges (Bourke \& Harwood 2009).

Kugmumb is located close to Mount Hagen, the capital of the Western Highlands. The general infrastructure in Kugmumb includes a road that links it to the capital city, which makes it easy for the town bus to drive to the village. Electricity, television reception and water supply are connected to some but not all households and mobile phones can be seen everywhere. There are primary, secondary and tertiary institutions within walking distance. The river Kum that runs through the village is used as a dam to supply the residents and surrounding villages. The water supply for the city of Mt Hagen is derived from Kugmumb and, for the city residents, it is the only source of water, apart from rainwater for some houses that have tanks.

Both Lealea and Kugmumb have access to nearby urban centres. Kugmumb is located about $8 \mathrm{~km}$ from Mt Hagen city and Lealea about $30 \mathrm{~km}$ out of Port Moresby. Generally, both villages have good transportation and road systems that link them to the main cities, schools and health centres (NRI 2010), as well as to markets, shops, electricity and water sanitation. These are general infrastructures that are usually missing in the more remote villages of PNG. Houses in Kugmumb are a mix of huts and modern houses, but those in Lealea are almost all modern, 
semi-permanent and built on stilts. However, inequality is evident and most households do not have electricity or proper sanitation. These are available only to those who can afford them.

\section{General Livelihoods}

People in the villages of Kugmumb and Lealea have diverse livelihoods and income strategies that are changing and becoming more complex. Agriculture and natural resources-based activities have been common and important to their livelihoods. However, households in these villages today have diversified into other activities; these strategies for this diversifying include subsistence production and production for sale at markets, as well as participation in the labour market. Jobs vary from office administration, construction and building to teaching, medical professions and others. However, youths in the villages are mostly unemployed.

In Lealea, many gardens have been neglected because of the effect of the LNG plant, which is situated on the Lealea people's customary land. However, the initial pulse of wage-labour income that originally accompanied the construction of the LNG plant has ended and people are now readjusting to gardening. A growing number of women sell both garden produce (particularly betel nut) and store goods at the markets. Youths who were casually employed during the construction phase of the LNG plant are struggling to find other means of getting employed for wage labour. The promises and dream of having more money and wealth from the LNG project has not been realised, which has been frustrating for the villagers - and especially for the youths.

Livelihoods in the villages near towns and urban centres are quite different from those further away and are changing rapidly. Robert Chambers and Gordon Conway (1992) said that a livelihood comprises the capabilities, assets (including both material and social resources) and activities that are required for a means of living. A livelihood is sustainable when it can cope with and recover from stresses and shocks, and when it can maintain or enhance its capabilities and assets while not undermining the natural resource base. Sustainable livelihood frameworks (DFID 2000; Ellis 2000) aim to conceptualise how people function within a vulnerability context that can be caused by different factors-shifting seasonal constraints (and opportunities), economic shocks and longer-term trends and how they draw on different types of livelihood assets or capitals in different 
combinations. The different assets include those of a financial, natural, physical, human and social kind. These are influenced by the vulnerability context, a range of institutions and processes and how they use their asset base to develop a range of livelihood strategies for achieving their desired livelihood outcomes (Scoones 1996).

Youths in both villages have faced shocks that have left them vulnerable. These shocks vary, as they were experienced by different members in the villages. For youths, shock includes becoming unemployed, discontinuation in the educational system and returning to the village, where no formal systems are in place to support reintegration. Hence, more problems arise, as the youths who miss out on employment and tertiary education demonstrate antisocial behaviour. The following case study illustrates some of the complex social effects of frustrated development aspirations in rural PNG.

\section{Death and Violence: A Case Study}

Dinga $^{1}$ died after a long illness. He had completed Year 10 at a local high school, but never continued to further his education because he did not pass the national exams. Frustrated that he was considered a failure in the village, he went to live with relatives in town and there he met his wife. They had a son when they both came back to live in the village.

Dinga was 28 years old and had been sick for months. He had been going in and out of the hospital, but he could never recover. The family reported that the doctors could not diagnose what was wrong with him. He would thus spend days in the house and village, and Christian groups would pray for him. These groups were from different denominations and would take turns praying for Dinga. He was part of the music ministry in the local Pentecostal church and played bass guitar in the music team at the church. In the weeks leading up to Dinga's death, his mother, wife and son, together with other believers, spent days and nights praying in the church, hoping for a miracle that unfortunately never came.

1 Names used in this chapter are pseudonyms. 


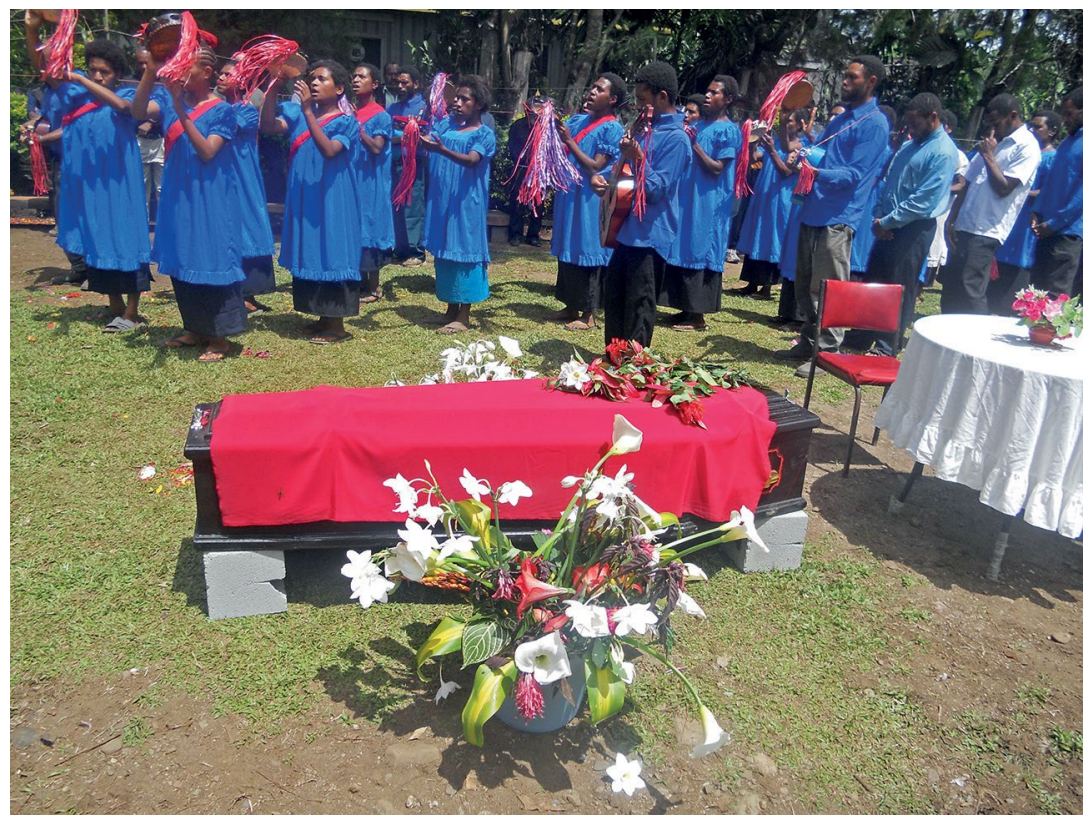

Figure 1. Funeral service of late Dinga.

Source. Author.

The funeral was arranged. Normally, funerals in the village are week-long, official and communal activities that not only allow the family to grieve, but the community and tribe as a whole as well. The whole community gathered officially at the ples singsing, a common big and open space in the middle of the village. Men, women and the young are all expected to sit in the open sun and take part in the official traditional hauskrai (mourning as a community). Neighbouring tribes and extended relations also come to pay respect and to help, which strengthens communal ties. During this time, it is expected that no one does gardening, bush clearing, house building or any big manual jobs. Entertainment of any sort or expressions of happiness are generally frowned upon. If one is seen ignoring the mourning, it is believed that they had a part in the death, that they are pleased by the death or that they have no feelings of empathy and sympathy.

On the second day after Dinga's death, the village was deep in mourning. At about $6.00 \mathrm{am}$, the unusual quiet was interrupted only by the slow sobs of the mother, aunty, wife and some of the women in their houses. Later, around $8.30 \mathrm{am}$, they all moved to the ples singsing to congregate 
and have the hauskrai. Suddenly, a commotion erupted with screams and wailing, as angry men rushed to bash a woman that they believed had used sorcery to cause Dinga's death.

Everyone ran to the scene to find out what was wrong, including the people I was staying with. From far through the coffee trees, I could see enraged young men in their late teens and early 20 s surround a poor woman, throwing punches at her. I struggled to identify the woman and realised that it was the wife of the late Dinga's father's cousin. She is regarded as a real family member. As I got closer, I could hear them screaming as they raged and punched her in anger.

The poor woman was helplessly fighting back to free herself, but she was overpowered by men on top of and around her who threw punches and kicks. I noticed that one was wearing large boots and kicking so hard that I thought she might be killed, but after 30-45 minutes of constant physical abuse, they finally let her go; however, it did not end there.

The men demanded that she explain why she went to the garden so early to plant peanuts and corn. Culturally, the norm is that once somebody dies, relatives are not supposed to do any gardening or other physical work. Having been caught planting, prior rumours that she had performed sorcery were now quickly 'confirmed'.

She was very bruised and traumatised. While this was going on, her husband and her 23-year-old son, about the same age as her attackers, looked on. They could not do anything, or they would too be bashed, tortured or worse. I was shocked, as I had never witnessed something like this before. Among the onlookers were university graduates, but surprisingly no one called the police; the idea was so remote, and everyone seemed to think that the police and local court system had no part to play in this. Most of the young men who bashed the poor woman were known to drink homemade 'jungle juice' (alcohol) and to take drugs, and all had dropped out of the formal education system at about the age of $16-18$ years.

Two of them needed money so badly that they had to steal goods from other villagers and sell them. On one occasion, they decided to steal a huge pig from their own aunt who fed them, so that they could obtain money for their needs. They planned it for the middle of the night when everyone in the village was still asleep but, when they walked into the marketplace, they were discovered and the theft was reported to the 
owner. When they were caught, the police were called and the young men were quickly arrested. However, the violence related to the sorcery incident was never reported to the police because such issues are resolved at the village level with customary laws. It showed how easily vulnerable women are abused.

\section{Antisocial Behaviour and Its Implications in Villages}

The behaviour described above reveals the intense frustration felt by youth. Many young men and women hang around in the villages doing nothing after dropping out of the education system. They discover that what they have learned is of little practical use and they look for ways to vent their frustrations. Typically, they make and drink home brew and cause antisocial behaviour. When they are drunk, males sometimes steal food items from gardens, as well as break into houses for food and other items for sale (UNICEF 2005).

Lulu is a mother in her 50s. She works hard to look after children who are not her biological children. The following is the disappointment that Lulu expressed at falling victim to such behaviour:

The other day, somebody went in and chopped the strong banana [kenenga] from the garden. I went to harvest it to sell the next day, but it was gone in the night. Later, I realised it was stolen by some of the young men. They are so lazy and stupid. Why can't they work?

Bopi is a man who is also in his 50s. He said that he too fell victim:

Two weeks ago, I am building a house. I had all my building materials outside in the shed. One day I was to put the windows to my house, but I realised some were missing. I quickly investigated that some young men have taken them and sold them.

When young men see other members of the family with jobs, money and a 'better' material life than them, they take out their frustration and resentment on innocent people. In former times, stealing from family members was never an option but, because of their desperation to have money, these young men turn to antisocial behaviour such as stealing pigs to sell. Economic inequality thus contributes to the increase in violence and other forms of antisocial behaviour (Wilkinson \& Pickett 2009). 
The rising cost of living in PNG creates an ever-widening inequality between those who have cash incomes and those who do not (Martin 2007). This often leads to jealousy within communities between the economically advantaged and disadvantaged groups. As a result, when sorcery issues arise, people release their frustrations. The intense discontent created by economic imbalances in society is often triggered by the widespread belief in sorcery, which typically results in violent and antisocial behaviour.

The young men's violence and stealing also show that the social structures and institutions, which hold societies together, are becoming weak and are gradually crumbling. Today, a new social group is emerging in the communities. They are known as 'drug bodies', which are groups made up of young people who have no perspective in life and who have no hope for the future (UNICEF 2005). They become a danger to communities because of their association with drugs and violence. In times of social crisis such as sickness and death, sorcery accusations and retribution are often led by young drug takers.

Village elders and traditional leaders speak out and do their part, but they are no longer being respected by young people who seek identity and acknowledgement in society. Social unity within families and clan communities drops, as sorcery-related violence causes social fragmentation. Traditional values of communal life and social systems are increasingly being tested as materialism and individualism rise. This also results in the culture of greed and corruption, while the social and economic life of sharing, caring and helping is gradually losing its value. The collapse of traditional social systems promotes the culture of sorcery accusations and other violent behaviours (Forsyth 2016). The breakdown in social order and generational conflict between the old and young also leads to the increase in antisocial behaviour.

This is what a community leader from Lealea village said regarding young people's antisocial behaviour:

Young people, especially males, would turn to drugs and brewing homemade jungle juice commonly known as 'steam'. These containers [see Figure 2] have been confiscated last month because they use these containers to brew their steam. When they are drunk and controlled by drugs, they make noise, seek attention, destroy things, act violently and fight. 


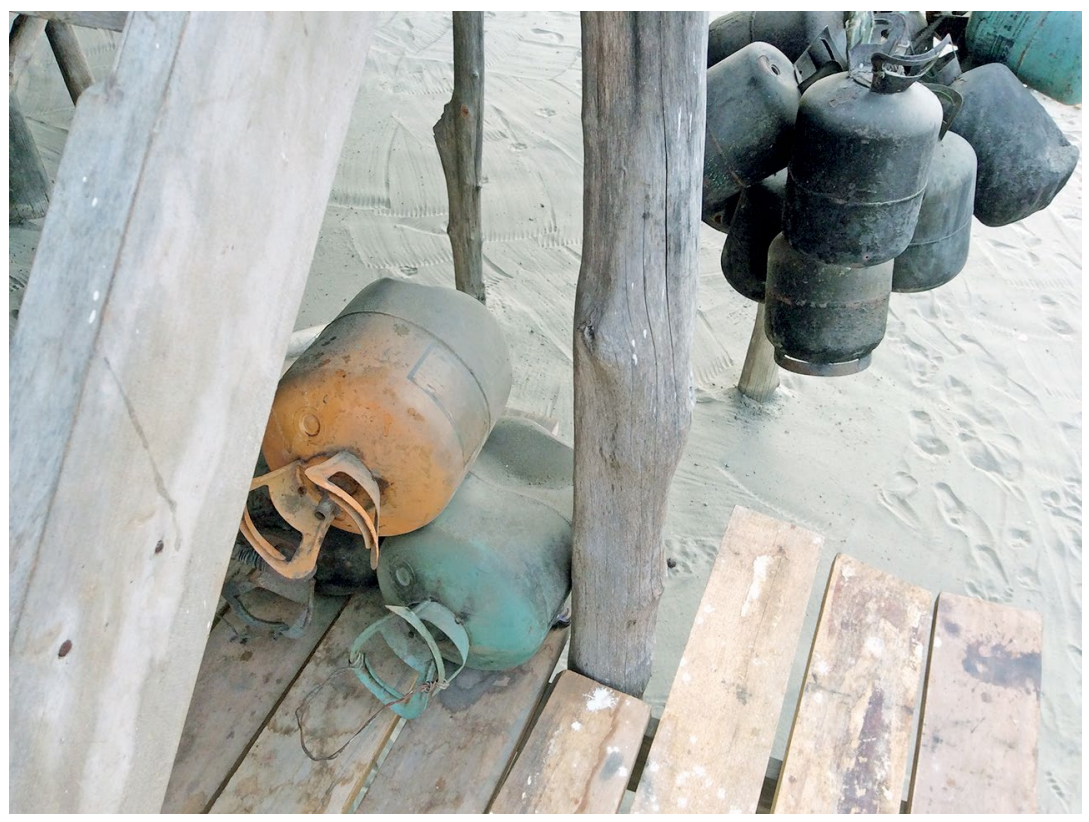

Figure 2. Brewing containers confiscated in Lealea village.

Source. Author.

Another aspect of social change is that unrealised expectations of a better life lead to innocent people falling victim to violence and antisocial behaviour. Minimal support and opportunities for improved livelihoods causes social stress among people and contributes to an increase in these behaviours. Lack of economic and infrastructural development in rural areas, failure in school, failure in business and failure to find employment result in more stress. Rapid changes brought about by modernisation have changed people's perception of life and create confusion, disorientation and social tension. Promises of development and improved livelihoods do not transpire. When these expectations are not met, people resort to sorcery, drugs and violence as a means of seeking answers and making their deep concerns known.

This is what a woman aged 27 years old from Lealea had to say:

Before the Liquefied Natural Gas was going to be extracted here, we were told that our village would have very good modern permanent houses with water running inside. We would have so much money too because we are landowners. That was all a lie, because look at us now. We are still poor and have not improved. Things are not as expected. People, especially young people, are 
turning to drugs and steam. They are lazy and do nothing. People imagine and dream of a good life. A good life is living in modern, permanent housing with electricity and proper sanitation. There would be enough money to use and save for school fees and other needs and, at the same time, they want sealed roads connecting them to cities and towns with good transportation.

The wishes of people are stronger and larger than the reality. The reality is that these wishes take time to be realised and they do not come easily; it takes hard work and effort. The resources and systems of governance, management and delivery that are in place do not work effectively; while some are aware of corruption in the system, they either accept it or do not know how to address it. Finally, people have deep belief systems that explain deaths and dilemmas for them better than what many outsiders would regard as facts. People are so deeply rooted in their belief systems that they are not able to accept alternative world views. Disease and illness have medical explanations, but these are overlooked and, instead, causality is explained through supernatural belief systems. Many people also lack knowledge about health, hygiene and healthy lifestyles. When people die from accidents or lifestyle diseases such as diabetes, innocent people are blamed. People die young due to risky behaviour and unhealthy lifestyles, yet relatives often attribute the deaths to sorcery (Urame 2015).

To make matters worse, many people in positions of authority and responsibility, such as medical workers, police, church pastors and educated elites, continue to believe in the power of sorcery and witchcraft. This implies that in PNG, the level of education, social standing, profession and leadership of many people does not play a significant role in influencing people's belief systems. For example, a young woman who recently graduated from the formal education system said:

I completed my schooling as a Grade 12, but I never got to university because people are jealous so they used sorcery to stop me from continuing. 


\section{Implications: PNG's Social, Economic and Political Environment}

\section{Weak Political Governance and Corruption Contributes to Youth's Displaced Aggression}

PNG is one of the "weak states in a region characterised by corruption, an absence of "good governance" and "civil society" and increasingly subject to violence' (Patterson \& Macintyre 2011, p. 9). The violence and antisocial behaviour are displaced aggression. Youths that are pushed out of the education system are marginalised in many ways because there is no good structural and formal leadership for them to have a voice and make decisions. Leadership is needed to have formal programs and institutions that specifically target such youths to help and integrate them into society. Unfortunately, this is absent. Leaders are caught between two worlds of traditional modern leadership that are influenced by capitalism and individualism, which has been challenging and problematic (McLachlan 2018).

PNG has kept a good record as a democratic government, but the vision of pre-independence leaders has not translated into a sense of national identity and purpose. This is because politics at the local and electoral levels are narrow and, at the national level, politics is manipulated by individuals who serve personal interests in the short time that they are in power (Kama 2017b). Such attitudes and behaviours have caused problems in the lives of common citizens like the youths. Political leaders are driven by personal and individualistic interests, not by the interests of youth.

Political parties have not developed to play the expected role of selecting candidates, articulating issues and keeping MPs accountable; there has been little development of a civil society, and the quality of governance has been poor (Kama 2017a). For example, during elections, Bitu, a man in Kugmumb, said:

People, especially men, are cunning at elections. They go to candidates' campaign places, get money promising to cast their votes but, when at polling, they vote for their relative or someone whom they will benefit from in terms of employment or material goods. They really don't care about the policies and parties. In fact, most do not understand. 
At the national level, this is what a minister said when asked why the O’Neill government could not be replaced easily:

The reason is because DSIP (District Services Improvement Programme) is there, that's why we will be in the government and support the O'Neill-Dion government. It's not about your number of qualifications you have to lead the government; so long as you have the money, you will master the numbers (Kama 2017a).

PNG has a political system that is unstable and corrupt. A local retired public servant said this:

Today, we have a bunch of men who have so much money that, with it, they can do anything to get into power and control—get the sweet little sixteen who just finished high school, bribe the policeman and go free if they have done wrong. Members of the tribe look up to him as a god because they represent the tribesmen. They will help more in terms of communal activities whenever such activities come up once in a while. Other than that, the rest of the time and most of his money and resources belong to themselves and their family. Even though individuals complain that such men are greedy and do not share, that does not matter. It is the name of the tribe he promotes which is their pride.

Corruption has had detrimental effects on the nation of PNG. Corruption has undermined sustainable economic development, ethical values and justice; it has destabilised the society and compromised the rule of law. It has weakened the institutions and values of our democracy. Acts of corruption at varying levels have deprived citizens of their constitutional and human rights (Kama 2017a). Frustrated citizens like youths are deprived of their rights and opportunities so they turn to violence and antisocial behaviour.

PNG has allowed corruption to grow systematically for the last 42 years. This has resulted in ordinary youths' and citizens' lives being made more difficult and in their opportunities being limited. Inefficiencies and dysfunction in the public service have impeded progress. Loopholes have been created in legal and administrative systems that allow manipulation and distortion of democratic values, which deprive citizens of their basic human rights and trap millions in poverty.

Corruption has been accepted as a norm. People regard it is as part of the way of life. This is because of PNG's so-called 'big men', who take whatever they want and do whatever they want. They have become a law 
unto themselves, powerful and untouchable. All citizens have become their victims. This big man culture is practised alongside democracy and modern politics causes many problems (Gewertz \& Errington 2004; Wyeth 2017). Different systems of government-traditional forms and the modern introduced version-cause confusion and compound the problems.

\section{Controlled and Mismanaged Economy Contributes to Youth's Displaced Aggression}

The dual economy of PNG has a small (in terms of the number of employees) formal sector, focused mainly on the export of natural resources, and an informal sector that employs most of the population. Agriculture provides a subsistence livelihood for 85 per cent of the people (NRI 2010). There is a youth bulge.

Youth unemployment is high in PNG, with young people in urban areas living day-to-day, often causing opportunistic crime to survive and leading lives without direction. And though the informal sector is burgeoning, life for these young people is tenuous and uncertain (McLachlan 2018).

The formal sector consists mainly of workers who are engaged in mineral production, forestry and fisheries, a relatively small manufacturing sector, public sector employees and service industries, including finance, construction, transportation and utilities. Most of the population is engaged in the informal sector. Youths' migration into major city centres in the past decade has contributed to urban unemployment and social problems.

Mineral deposits, including copper, gold and oil, account for nearly two-thirds of export earnings. The government faces the challenge of ensuring transparency and accountability for revenues flowing from this and other large LNG projects. The government still faces numerous challenges, including providing physical security for foreign investors, regaining investor confidence, restoring integrity to state institutions, promoting economic efficiency by privatising declining state institutions and maintaining good relations with Australia, its former colonial ruler. Other sociocultural challenges could collapse the economy, including chronic law and order and land tenure issues. All these factors mean that the kind of future and environment for youths is not promising. There is vulnerability and their livelihoods are not sustainable. 
PNG is dependent on foreign aid because a large part of the economy and technology is foreign and controlled by transnational corporations with entities in donor countries. Most of the wealth created by these foreigners inevitably leaves the country (Mousseau \& Lau 2015), with just enough that is distributed locally to keep the system operating. The foreign-owned part of economy has not stimulated local economic development nearly as much as the transnational companies have promised. PNG's economy brings wealth for elites and impoverishment for most of the population, including youths. The problem has worsened, as the government continues to borrow. The growth of national debt has emerged as a key weakness of many third-world countries (Rapley 2002). For instance, PNG's total public debt is expected to increase by more than PGK4 billion from the projected 2017 budget estimate of PGK22 billion, according to the PNG Treasury Department (Patjole 2017).

\section{Sociocultural Challenges Contribute to Youths' Displaced Aggression}

PNG faces challenges with human rights, especially in relation to women and children. A UNICEF study of orphans and vulnerable children showed that 68 per cent of women have experienced violence in the home-though this is as high as 90 per cent in some communities in the highlands provinces (UNICEF 2005). Many girls in PNG are at risk of commercial sexual exploitation, and one-third of all sex workers are under the age of 20. This is because of the pressure to meet basic needs in a struggling socioeconomic environment. Expectations from family and relatives are there too. They turn to commercial sex and other risky behaviours to survive.

For example, one young woman aged 20 said:

I live in a settlement area; my parents do not have a job now. I did not continue to college because my parents could not afford school fees. Living in such [a] harsh environment forced me to look for money to survive. Since there is no job for people like me, I saw that the easiest way was to get money from men who had money, so I went out with them.

UNICEF reports that 80 per cent of the population is yet to have their births registered and that 22 per cent of children reside away from their biological parents. Girls and young women are the most abused and 
vulnerable. Some 75 per cent of children who come into conflict with the law experience police abuse (UNESCO 2007a). These figures show that youths are neglected and are the most victimised structurally.

Community obligations push against the individualism that is demanded by global market logics. These factors have an effect on communities, families and children. Marriage breakups or change of partners by one or both parents are not uncommon, putting children in the middle of new relationships. Stepfathers or non-biological members of new families can expose the child to sexual abuse, violence or neglect.

Generally, issues are complex and stem from poverty, unequal power structures and gender roles, subordinate status of women in society, women's economic dependence on men, lack of land rights and their overall lack of power in the decision-making process (Dyer 2016; Sepoe 2002). Other compounding factors are ethnic diversity and language, urban migration, abuse of alcohol and illicit drugs, polygamy and changing traditional customs. In PNG, women and young girls are a particularly vulnerable group (ILO 2011). They are vulnerable to violence and harassment of all forms.

Further, weak infrastructure, weak service delivery mechanisms, marketing difficulties and low government and civil society capacity reduce the possibilities of alternative livelihoods. With about 87 per cent of the population living in rural areas, this is a major concern (UNESCO 2007b).

\section{Conclusion}

The antisocial behaviour and other problems that youths face are a result of many factors. Displaced aggression is the result of youths looking for opportunities to release their frustrations as victims of structural deprivation. Livelihoods for some communities that are near towns or cities and those communities affected by extractive industries are becoming unsustainable. Youths and the young adults are the ones that need urgent attention. High population growth and the low median age means that the country is facing huge youth challenges, especially with the high potential for the population to grow further (NSO 2011) This puts pressure on the country to invest a large proportion of its resources in social services such as health and education, as well as in employment creation. 
It is increasingly evident that the fruits of globalisation benefit mainly the elite and that, in many countries, the poor become more marginalised and more impoverished (Jason 2017). This trajectory will see more conflict and more suffering (Saskia 2014). All governments, including PNG, go to UN meetings and vote that the poor and marginalised like the youths must be given priority and that there must be more progress. The systematic reduction of poverty is the point of the development relationship. This message is repeated at the World Bank, in UN agencies, in the Asian Development Bank, the African Development Bank, the European Union and the International Monetary Fund. But, will the rural poor and this growing, deprived population of youths really feel the benefit? Development in PNG is not focused on people as the centre. People, and especially youth, are affected detrimentally because of the complex issues discussed in this chapter.

\section{References}

Bourke, M \& Harwood T (eds) 2009, Food and agriculture in Papua New Guinea, ANU E Press, Canberra, doi.org/10.22459/FAPNG.08.2009

Chambers, R \& Conway, G 1992, Sustainable rural livelihoods: Practical concepts for the 21st century, Institute of Development Studies, Brighton, England.

Cornwall, A 2016, 'Women's empowerment: What works?', Journal of International Development, vol. 28, no. 3, pp. 342-359, doi.org/10.1002/jid.3210

DFID 2000, Sustainable livelihoods: Current thinking and practice, DFID, London.

Dyer, M 2016, 'Eating money: Narratives of equality on customary land in the context of natural resource extraction contests in the Solomon Islands', The Australian Journal of Anthropology, vol. 28, no. 1, pp. 88-103, doi.org/ 10.1111/taja.12213

Ellis, F 2000, Rural livelihoods and diversity in developing countries, Oxford University Press, Oxford.

Forsyth, M 2016, 'The regulation of witchcraft and sorcery practices and beliefs', Annual Review of Law and Social Science, vol. 12, pp. 331-351, doi.org/ 10.1146/annurev-lawsocsci-110615-084600

Gewertz, D \& Errington, F 2004, Emerging class in Papua New Guinea, Cambridge University Press, Cambridge. 
ILO 2011, Child labour in Papua New Guinea: Report on the rapid assessment in Port Moresby on commercial sexual exploitation of children and children working on the streets 2011, IPEC, Geneva.

Jason, H 2017, 'Is global inequality getting better or worse? A critique of the World Bank's convergence narrative', Third World Quarterly, vol. 1, p. 15, doi.org/10.1080/01436597.2017.1333414

Kabeer, N 1999, 'Resources, agency, achievements: Reflections on the measurement of women's empowerment', Development and Change, vol. 30, no. 3, pp. 435-464, doi.org/10.1111/1467-7660.00125

Kama, B 2017a, An analysis of Papua New Guinea's Political Condition and Trends through to 2025, Lowy Institute, viewed 18 February 2018, interactives.lowy institute.org/archive/png-in-2017/png-in-2017-png-political-conditionto-2025.html

Kama, B 2017b, PNG in 2017: A year of redefining deomcracy?, Devpolicy Blog, 27 January, viewed 18 February 2018, www.devpolicy.org/png-2017-yearredefining-democracy-20170127/

Martin, K 2007, 'Your own Buai you must buy; the ideology of possessive individualism in Papua New Guinea', The Anthropological Forum, vol. 17, no. 3, pp. 285-298, doi.org/10.1080/00664670701637743

McLachlan, S 2018, 'Youths in PNG: Challenges to building a positive future', Devpolicy Blog, 27 January, viewed 18 February 2018, www.devpolicy.org/ youth-png-challenges-building-positive-future-20180117/

Mousseau, F \& Lau, P 2015, The great timber heist: The logging industry in Papua New Guinea, Oakland Institute, Oakland, CA.

NRI 2010, Papua New Guinea district and provincial profiles, National Research Institute, Port Moresby.

NSO 2011, Papua New Guinea national population and housing census 2011, NSO, Port Moresby.

Patjole, C 2017, Mid-year economic and fiscal outlook report, Loop PNG.

Patterson, M \& Macintyre, M 2011, Capitalism, cosmology and globalisation in the Pacific, University of Queensland Press, Brisbane.

Rapley, J (ed.) 2002, Understanding development: Theory and practice in the third world, Lynne Rienner, London.

Saskia, S 2014, Expulsions: Brutality and complexity in the global economy, The Belknap Press of Harvard University Press, Cambridge, MA. 
Scoones, I 1996, Hazards and opportunities. Farming livelihoods in dryland Africa: Lessons from Zimbabwe, Zed books, London.

Sepoe, O 2002, 'To make a difference: Realities of women's participation in Papua New Guinea politics', Development Bulletin, no. 59, pp. 39-42.

Sholkamy, H 2010, 'Power, politics and development in the Arab context: Or how can rearing chicks change patriarchy?', Development, vol. 53, no. 2, pp. 254-258, doi.org/10.1057/dev.2010.26

UNDP 2015, Human development report: Work for human development, UNDP, viewed 4 March 2018, hdr.undp.org/sites/default/files/2015_human_ development_report.pdf

UNESCO 2007a, Country programming document_Papua New Guinea; 20082013 (vol. 6), UNESCO, Apia.

UNESCO 2007b, Country programming document 2008-2013, UNESCO Cluster Office for the Pacific States, Apia.

UNICEF 2005, The state of Pacific youth 2005, Secretariat of the Pacific Community, Noumea.

Urame, J 2015, 'The spread of sorcery killing and its social implications', in M Forsyth \& R Eves (eds), Talking it through: Responses to sorcery and witchcraft beliefs and practices in Melenesia, ANU Press, Canberra, doi.org/10.22459/ TIT.05.2015.01

Wilkinson, R \& Pickett, K 2009, The spirit level: Why equality is better for everyone, Penguin, London.

Wyeth, G 2017, 'Big men, no women: Politics in Papua New Guinea', The Diplomat, 11 August, viewed 18 February 2018, www.thediplomat.com/ 2017/08/big-men-no-women-politics-in-papua-new-guinea/ 
This text is taken from Pacific Youth: Local and Global Futures, edited by Helen Lee, published 2019 by ANU Press, The Australian National University, Canberra, Australia.

doi.org/10.22459/PY.2019.08 